\title{
Comparative Study of Active and Inactive Plasma Renin in Healthy Infants and Adults
}

\author{
By K. J. Van Acker, S. L. Scharpé, P. J. Lynen and A. K. Amery \\ Departments of Pediatrics and Clinical Chemistry, University of Antwerp and Hypertension and Cardiovascular \\ Rehabilitation Unit, University of Leuven, Belgium
}

(Received February 11/July 18, 1983)

\begin{abstract}
Summary: Active, inactive and total plasma renin activity ${ }^{1}$ (obtained after cryoactivation), active, inactive and total plasma renin concentration ${ }^{1}$ (obtained after acid activation) and plasma angiotensin II were measured in 20 healthy infants and in 20 healthy adults. Active plasma renin activity but not active plasma renin concentration or plasma angiotensin II were significantly higher in the infants. In the latter both cryoactivation and acid activation resulted in a nearly $100 \%$ increase of the mean active plasma renin activity or active plasma renin concentration. Therefore the active fraction represented 0.5 of total renin with both methods. This was different in adults, where acid activation was more effective than cryoactivation. In adults, plasma angiotensin II was correlated only with active plasma renin activity and active plasma renin concentration; in contrast, plasma angiotensin II of infants was correlated with both active plasma renin activity, and with inactive plasma renin activity.
\end{abstract}

Aktives und inaktives Renin im Plasma von gesunden Kindern und Erwachsenen - Eine Vergleichsstudie

Zusammenfassung: Aktive, inaktive und gesamte Plasma-Renin-Aktivität (erhalten nach Kryoaktivierung), aktive, inaktive und gesamte Plasma-Renin-Konzentration (erhalten nach Säureaktivierung) und Angiotensin II im Plasma wurden bei 20 gesunden Kindern und 20 gesunden Erwachsenen bestimmt. Die aktive Plasma-Renin-Aktivität, jedoch nicht die aktive Plasma-Renin-Konzentration oder Angiotensin II im Plasma war bei den Kindern signifikant höher. Sowohl Kryo- als auch Säureaktivierung ergaben für das Plasma von Kindern einen Anstieg der mittleren aktiven Plasma-Renin-Aktivität bzw. -Konzentration auf nahezu das doppelte, d. h. der aktive Anteil betrug 0,5 vom Gesamt-Renin in beiden Methoden. Im Unterschied dazu war für Plasma der Erwwachsenẹn die Säureaktivierung wirkșamer als die Kryoaktivierung. Bei den Erwachsenen war Angiotensin II im Plasma nur mit der aktiven Plasma-Renin-Aktivität und -Konzentration korreliert, im Plasma der Kinder jedoch sowohl mit der aktiven als aụch der inaktiven Plasma-Renin-Aktivität.

\section{Introduction}

In the human plasma, circulating renin is present in both an active and an inactive (prorenin) form. The

1) Definitions

Plasma renin activity is defined as the catalytic concentration of renin in native plasma, measured as angiotensin I liberated from the endogenous renin substrate

Plasma renin concentration is defined as the catalytic concentration of renin in dialyzed plasma after inactivation of endogenous renin substrate and angiotensinases, measured as angiotensin I liberated from nephrectomized sheep reviin subsirate under zero order kinetic conditions. latter can be activated in vitro by exposure of the plasma to cold (cryoactivation), low pH (acid activation) or treatment with proteolytic enzymes (1). Whether activation also occurs in vivo is not clear; although active and total renin but not inactive renin as determined in vitro, have a predictive value for the in vivo acute hypotensive effect produced by inhibitors of the renin-angiotensin system (2), the physiological significance of inactive renin remains still to.be elucidated. An aspect which has not yet been studied in children is the relative amounts of active and inactive renin in that age group. 
In the present study active and inactive renin were determined in healthy infants using both cryoactivation and acid activation and the results were compared to those obtained in an identical number of adults during an earlier study (3).

\section{Materials and Methods}

Twenty healthy infants, age 1 to 12 months (mean age 5.9 months) were studied: there were 11 boys and 9 girls. All had been admitted to the hospital for benign conditions and were awaiting dismissal. They were on the usual hospital diet with an estimated sodium intake of $0.75-2 \mathrm{mmol} / \mathrm{kg} \cdot \mathrm{d}$, independent of their age. They received no treatment known to affect the reninangiotensin system. Blood was drawn in the afternoon with the child in the recumbent position. In all cases informed consent was obtained from the parents. The data were then compared with those obtained during a previous study in 20 healthy adults, 22 to 45 years old (mean age $31.0 \pm 6.2$ years), who were on an unrestricted diet and in whom blood was drawn after an upright position had been assumed for 15 minutes (3). For the statistical analysis Student's two-tailed t-test and linear regression analysis were used. The dispersion of the data is given by the standard error of the mean (S.E.M.).

\section{Radioimmunoassay of plasma renin activity}

Plasma renin activity was measured by radioimmunoassay of the angiotensin I generated during a $1 \mathrm{~h}$-incubation of the plasma samples with the endogenous renin substrate at $\mathrm{pH} 6.0$ and at $37^{\circ} \mathrm{C}$ according to the method of Fyhrquist \& Puutula (4).

Renin activity was measured in plasma samples immediately after thawing and after storage of the plasma at $-5^{\circ} \mathrm{C}$ at $\mathrm{pH} 7.4$ for 4 days. The values of renin before and after exposure of the plasma to the cold are referred to respectively as active and total plasma renin activity. The difference between both is taken as inactive plasma renin activity.

Radioimmunoassay of plasma renin concentration

Total plasma renin concentration

The plasma was first dialysed for 24 hours against $0.05 \mathrm{~mol} / \mathrm{l} \mathrm{ami-}$ noacetic acid buffer $\mathrm{pH} 3.3$ containing $5 \mathrm{mmol} / \mathrm{I}$ EDTA and 95 $\mathrm{mmol} / \mathrm{NaCl}$ to denaturate irreversibly the endogenous renin substrate, then heated at $32^{\circ} \mathrm{C}$ for $1 \mathrm{~h}$ to inactivate the angiotensinases. A second dialysis against a $0.18 \mathrm{mo} / 1$ phosphate buffer $\mathrm{pH}$ 7.5 containing $1 \mathrm{mmol} / / \mathrm{EDTA}$ and $75 \mathrm{mmol} / \mathrm{h} \mathrm{NaCl}$ was performed for 24 hours. The $\mathrm{pH}$ 3.3-treated plasma was then incubated with an excess renin substrate from a nephrectomized sheep at $\mathrm{pH} 7.5$ at $37^{\circ} \mathrm{C}$ for $1 \mathrm{~h}$ under zero order kinetic conditions according to the method of Skinner (5). The generated angiotensin I was measured radioimmunologically according to the method of Fyhrquist \& Puutula (4).

\section{Active plasma renin concentration}

The plasma was first dialysed for 24 hours against a $0.18 \mathrm{~mol} / 1$ phosphate buffer $\mathrm{pH} 7.5$ containing $5 \mathrm{mmol} / \mathrm{EDTA}$ and 95 $\mathrm{mmol} / \mathrm{N} \mathrm{NaCl}$, heated at $32^{\circ} \mathrm{C}$ for 1 hour and dialysed for another 24 hours against a $0.18 \mathrm{~mol} / 1$ phosphate buffer $\mathrm{pH} 7.5$ containing $1 \mathrm{mmol} / \mathrm{l} \mathrm{EDTA}$ and $75 \mathrm{mmol} / \mathrm{/} \mathrm{NaCl}$. After incubation with an excess sheep renin substrate at $\mathrm{pH} 7.5$ at $37^{\circ} \mathrm{C}$ for $1 \mathrm{~h}$ the generated angiotensin I was measured by radioimmunoassay. The difference between the total plasma renin concentration and the active plasma renin concentration is taken to represent the inactive plasma renin concentration.
Angiotensin 11

A radioimmunoassay method was used for the measurement of the plasma angiotensin II concentration as previously described (6).

\section{Results}

\section{Results in the infants (fig. 1)}

The mean plasma renin activity increased from 3.85 \pm 0.48 to $7.54 \pm 0.77 \mu \mathrm{g} \cdot \mathrm{l}^{-1} \cdot \mathrm{h}^{-\mathrm{i}}$ after cold treatment of the plasma ( $p<0.001$ ). After acid treatment the mean plasma renin concentration increased from 24.3 to $48.1 \pm 3.3 \mu \mathrm{g} \cdot \mathrm{l}^{-1} \cdot \mathrm{h}^{-1}(\mathrm{p}<0.001)$. Of the total plasma renin activity, active and inactive plasma renin activity represented fractions of 0.510 \pm 0.037 and $0.490 \pm 0.037$ respectively. Of the total plasma renin concentration, active and inactive plasma renin concentration represented fractions of $0.485 \pm 0.050$ and $0.522 \pm 0.048$ respectively. There is no significant difference between the fractions observed with both methods $(p>0.10)$. The mean plasma angiotensin II concentration was $\mathbf{3 3 . 6}$ $\pm 4.3 \mu \mathrm{g} \cdot \mathrm{I}^{-1}$.

Plasma angiotensin II was significantly correlated with all three forms of plasma renin activity. Plasma angiotensin II was also significantly correlated with the active plasma renin concentration but not with the total or inactive plasma renin concentration,

\section{Results in the adults (fig. 1)}

The mean plasma renin activity increased from 0.96 \pm 0.13 to $1.63 \pm 0.19 \mu \mathrm{g} \cdot 1^{-1} \cdot \mathrm{h}^{-1}$ after cold treatment of the plasma ( $p<0.001$ ). After acid treatment the mean plasma renin concentration increased from $17.2 \pm 2.3$ to $50.5 \pm 4.7 \mu \mathrm{g} \cdot \mathrm{l}^{-1} \cdot \mathrm{h}^{-1}(\mathrm{p}<$ 0.001): Active and inactive plasma renin activity represented fractions of $0.61 \pm 0.026$ and $0.39 \pm$ 0.062 respectively of total plasma renin activity while active and inactive plasma renin concentration represented fractions of $0.34 \pm .0 .026$ and $0.66 \pm$ 0.026 respectively of the total plasma renin concentration. The difference between the fractions observed with both methods is significant $(p<0.001)$. The mean plasma angiotensin II concentration was $27.9 \pm 3.6 \mu \mathrm{g} \cdot 1^{-1}$.

The plasma angiotensin III concentration was significantly correlated with active and total plàsma renin activity but not with inactive plasma renin activity. It was not correlated with the active or inactive plasma renin concentration and marginally correlated with the total plasma renin concentration. 

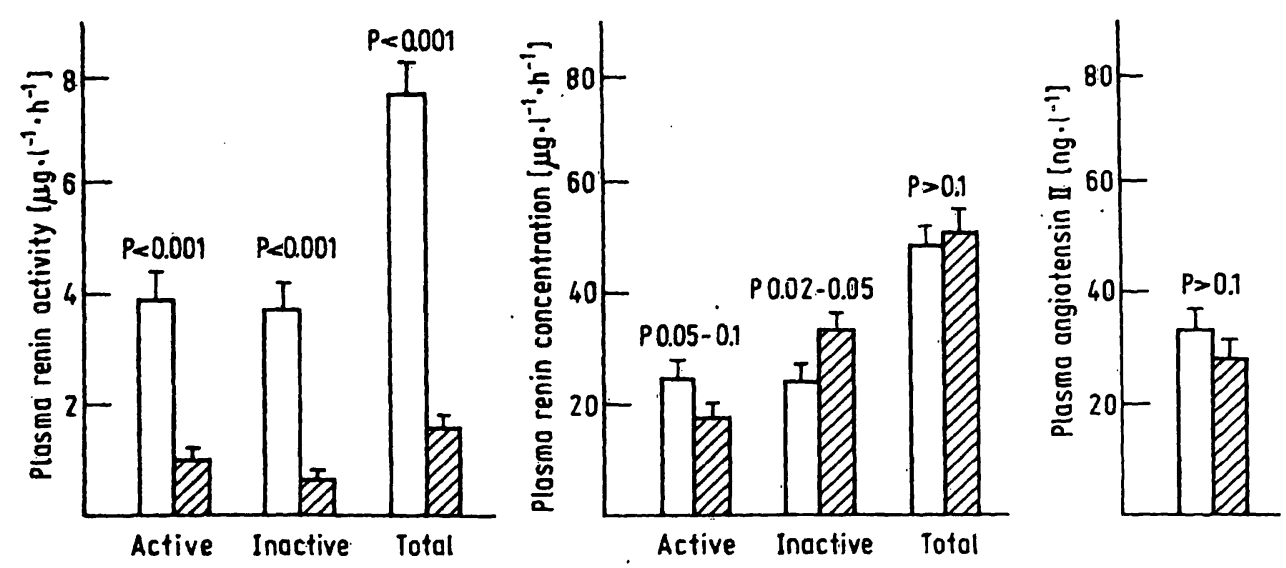

Fig. 1. Mean value ( \pm SEM) for active, inactive and total plasma renin activity; active, inactive and total plasma renin concentrations and plasma angiotensin II in 20 healthy infants (open columns) and 20 adults (shaded columns).

\section{Comparison between infants and adults (fig. 1)}

All three forms of plasma renin activity are 4 to 5.5 times higher in infants than in adults: the difference is significant $(p<0.001)$. In contrast there is little difference between the values of plasma renin concentration in the infants and the adults: the difference is significant only for the inactive plasma renin concentration $(p=0.02-0.05)$. Also there is no statistically significant difference between the plasma angiotensin II values in both age groups.

Whereas in the infants plasma angiotensin II was correlated with all three forms of plasma renin activity, it was correlated only with active and total plasma renin activity in the adults. In the infants plasma angiotensin II was significantly correlated only with the active plasma renin concentration, whereas in adults it was correlated with the total plasma renin concentration.

\section{Discussion}

In children and especially in infants, the values of plasma renin are high compared with those in adults $(1,7,8,9)$, but there is as yet no convincing explanation of this finding. A study of active and inactive renin in infants may throw some light on the mechanisms which are responsible for the increased renin values in that age group. Very little is known about prorenin in the child or young animal. In the foetal lamb prorenin levels are high; renin inhibition with angiotensin II or stimulation with saralasin leads to a response of prorenin which is different from that of active renin, suggesting a discrete control mechanism of prorenin which is separate from that of active re$\operatorname{nin}(10)$.
We confirmed our earlier finding that active plasma renin activity values are higher in infants (11). Active plasma renin concentrations, however, were not significantly different in infants and adults and in agreement with this, plasma angiotensin II values were also only slightly higher in the infants.

Our study further showed that the plasma of infants also contains inactive renin which can be activated in vitro by cold or acid treatment; inactive plasma renin activity, total plasma renin activity and the inactive plasma renin concentration are significantly higher in infants. There are some apparent differences with the adults. In the latter the proportion of active to total renin depends on the activation method which is used: with cryoactivation active renin represents a fraction around 0.61 of total renin while it is only around 0.34 with acid activation (3). In infants, however, both cryoactivation and acid activation resulted in a nearly $100 \%$ increase of the mean active plasma renin activity or active plasma renin concentration, so that the active fraction represents 0.50 of total renin with both methods. One can as yet only speculate on the cause of this difference between adults and infants. The mechanisms which are involved in the renin activation process are presently the subject of intensive research, but there are sufficient indications that the kallikrein-kinin system and the coagulation cascade and fibrinolysis are involved $(12,13)$.

Studies in adults which showed a correlation of plasma angiotensin II with the active but not with the inactive form of renin, suggested that inactive renin does not produce angiotensin II in vivo $(1,3)$. In the infants the same conclusion was reached for the inactive renin concentration but not for the inactive renin activity. An interpretation of this finding remains hazardous until we have a better insight in the underlying activation mechanism(s). 


\section{References}

1. Leckie, B. J. (1981) Clin. Sci. 60, 119-130.

2. Lynen, P., Amery, A. K., Fagard, R. H. \& Verschueren, L. (1980) J. Endocrinol. 85, 137-234.

3. Lynen, P. J., Amery, A. K. \& Fagard, R. H. (1979) Clin. Chim. Acta 95, 227-234.

4. Fyhrquist, F. \& Puutula, L. (1978) Clin. Chem. 24, 115-118.

5. Skinner, S. L. (1967) Circ. Res. 20, 391-402.

6. Lijnen, P., Amery, A., Fagard, R. \& Katz, F. (1978) Clin. Chim. Acta 88, 403-412.

7. Broughton Pipkin, F., Smales, O. R. C. \& O'Callaghan, M. J. (1981) Arch. Dis. Childh. 56, 298-302.

8. Dillon, M. J. \& Ryness, J. M. (1975) Br. Med. J. 4, 316-319.
9. Hiner, L. B., Gruskin, A. B., Baluarte, H. J. \& Cote, L. M (1976) J. Pediatr. 89, 258-261.

10. Siegel, S. \& Parkhill, T. (1980) Pediatr. Res. 14, 1353-1355.

11. Van Acker, K. J., Scharpé, S. L., Deprettere, A. J. R. \& Neels, H. M. (1979) Kịdney Internat. 16, 196-203:

12. Derkx, F., Bouma, B., de Bruyn, J. \& Schalekamp, M. (1981) In: Heterogeneity of Renin and Renin-Sứbstrate (Sambhi, P., ed.), Elsevier, New York, pp. 131-137.

13. Osmond, D., Tatemichii, S., Wilczynksi, E. \& Purdon, A. (1981) In: Heterogeneity of Renin and Renin=Substrate, (Sambhi, P., ed.), Elsevier, New York, pp. 139-157.

Prof. Dr. S. Scharpé Department Clinical Chemistry University of Antwerp

Universiteitsplein 1

B-2610 Wilrijk 